pollution due to municipal solid waste is the lack of a high-quality management system in the field of MSW management, and especially the outdated waste collection and transportation scheme. The state of MSW management does not meet modern requirements. At the landfill, as a result of the introduction of the technology for the production of biogas from municipal solid waste, it is possible to obtain marketable products - biogas and compost. The city can receive income from the use of biogas as an alternative source of energy for heating buildings or from its consuming by the population.

For the city of Uman, the volume of biogas formation at the MSW landfill in 2018 would have amounted to $5,441,280 \mathrm{~m}^{3}$, and in $2019-5,424,930 \mathrm{~m}^{3}$.Thus, it is possible to obtain significant volumes of biogas for the production of both heat and electricity. As a result of the study, recommendations were developed to improve the system for collecting municipal waste in the city of Uman. One of the promising utilization methods of the municipal waste organic component in the city of Uman is anaerobic fermentation followed by composting of the resulting products.

Key words: municipal solid waste, biogas, compost, sorting line, landfill.

УДК 631.559: 635.4: 635.7

DOI 10.31395/2415-8240-2021-98-1-111-125

\title{
АДАПТИВНІСТЬ ТА УРОЖАЙНІСТЬ СОРТІВ ПОМІДОРА ДО УМОВ ЛІСОСТЕПУ УКРАЇНИ
}

\section{Н. В. ВОРОБЙОВА, кандидат сільськогосподарських наук Уманський національний університет садівництва}

Розширення сортименту овочевих рослин дозволяе збільшити різноманітність та виробництво вітчизняної овочевої продукиії, зокрема, помідора. У статті розглянуто і доведено результатами досліджень, що сорт суттєво впливає на формування врожайності помідора. Найбільш високоврожайними сортами помідора, що дає змогу отримати більші за біометричними показниками і масою плоду та вищу врожайність товарної продукиії $є$ Чудо, Вулкан $і$ Хорів, щэо дозволяе отримати 62,8-63,0 m/2а високоякісних плодів.

Ключові слова: помідор, сорт, листок, листкова поверхня, урожайність, якість плодів.

Постановка проблеми. Овочі займають одне 3 найважливіших місць у продовольчому балансі, оскільки вони містять необхідні речовини для організму людини. Помідор характеризується високою харчовою цінністю і $\epsilon$ джерелом цінних фітонутрієнтів $[1,5,7]$.

Найбільшими у світі виробниками помідора $є$ Китай, Мексика, Італія, Іспанія, США. В Україні залежно від кліматичних умов та вегетаційного періоду вирощують у рік 800-1200 тис. т помідора. Це не високий показник, і в країні усі можливості в найближчий період збільшити виробництво до 3- 
5 млн. т, що дозволить довести споживання плодів до європейського рівня. Такі зміни у виробництві можливі лише за вдалого поєднання використання нових високопродуктивних сортів 3 ефективним налагодженням насінництва i новітніми технологіями вирощування $[2,6,16]$.

Аналіз останніх досліджень i публікацій. Вивчення особливостей розвитку та вимог культури помідора до чинників навколишнього середовища $\epsilon$ визначальним на їх процеси росту. Слід зазначити, що не усі сорти помідора однаковою мірою відносяться до чинників навколишнього середовища. Сорти, виведені в зонах $з$ тривалим днем, вимогливіші до світла i, навпаки, відселектовані в місцевості з коротким днем, менш вимогливі. Встановлено, що на стадії розсади перші три тижні світло $є$ визначальним чинником росту і розвитку рослин. За їх даними, для нормального розвитку вегетативних i генеративних органів потрібна освітленість не менше 4-5 тис. лк, оптимальна 20 тис. лк [3].

Порівняно з іншими овочевими культурами помідор менш вимогливий до грунту i його можна вирощувати на різних за механічним складом грунтах. Оптимальна реакція середовища - $\mathrm{pH}$ 5,5-6,5. Задовільно росте як на слабокислих, так і на слабо-лужних грунтах [3].

Добрі врожаї дають помідори на легких структурних чорноземах, на грунтах, що добре прогріваються і багатих на органічну речовину. Важкі солонцюваті запливаючі грунти мало придатні для цієї культури. На піщаних і супіщаних грунтах врожаї помідорів значно нижчі, але достигають плоди тут раніше. Проте слід пам'ятати, на яких би грунтах помідори не вирощувалися, під них треба вносити достатню кількість добрив. Помідори чутливі до умов мінерального живлення. Для встановлення оптимальних норм добрив i раціональному їх співвідношенні враховують природні особливості грунтів, забезпеченість їх рухомими формами поживних речовин, удобрення попередників [3, 4].

Аналізуючи біотичні чинники, можна зазначити, що вони сприяють накопиченню та кращому споживанню елементів живлення [18]. Проте, інформації, що стосується помідорів та їх потреб до факторів навколишнього середовища $\epsilon$ недостатньо, і у більшій мірі вони стосуються закритого грунту. Для відкритого грунту, більшість інформації висвітлено для Лісостепової зони.

Рослини помідора не надто вимогливі до тепла, проте за $10^{0} \mathrm{C}$ вони припиняють ріст, а за температури нижче $15^{\circ} \mathrm{C}-$ не зацвітають. I навпаки, ріст рослин сповільнюється за температури $30^{\circ} \mathrm{C}$, а за $35^{\circ} \mathrm{C}$ він припиняється зовсім. Проте інші вчені рекомендують оптимальну температуру повітря для росту і розвитку для помідора $20-24^{0 \circ} \mathrm{C}$ вдень і $16-18^{0 \circ} \mathrm{C}$ вночі. Деякі автори [5] для росту і розвитку помідора рекомендують оптимальну температуру повітря $18-25^{0 \circ} \mathrm{C}$ і вночі $15-18^{0 \circ} \mathrm{C}$. Велике значення має співвідношення між денними $\mathrm{i}$ нічними температурами. Знижені нічні температури стимулюють диференціацію конуса наростання: за $8^{0 \circ} \mathrm{C}$ ріст кореня припиняється. Але враховуючи те, що в умовах відкритого грунту регулювати температурні 
режими майже неможливо виникає проблеми із коливаннями строкових та денних температур [4, 5-10].

Рослини помідора потребують низької відносної вологості повітря (60$65 \%$ ) і високої вологості кореневбирного середовища, тобто відрізняються високим водоспоживанням. За недостатніх поливів грунту, у жаркі сонячні дні спостерігається скручування листя, опадання квіток, зав'язей, розтріскування плодів [11-17]. Вимоги помідора до вологості повітря також неоднакові по періодах росту. У фазі розсади вона повинна дорівнювати 70-75 \%, в період від фази розсади до початку зав'язування плодів - 70 \% і в період плодоношення 60-65\% [16-22].

Багато зарубіжних і вітчизняних авторів відмічають, що високий рівень вологості скорочує випаровування, при цьому збільшується ризик нестачі кальцію або магнію. Проте ці рекомендації можливо виконати в умовах закритого грунту, а в умовах відкритого - майже неможливе $[13,14,15]$.

Отже, у проаналізованих літературних джерелах відмічена залежність помідора від біотичних факторів навколишнього середовища, що дає змогу в певній мірі прогнозувати особливості росту і розвитку рослин $[12,23]$. Проте, існують деякі дослідження в умовах відкритого грунту, щодо можливого використання певних агрозаходів, до яких відноситься кращий високоврожайний сортимент, що може мінімізувати негативний вплив факторів навколишнього середовища.

Методика досліджень. Експериментальні дослідження здійснювали у 2018-2020 рр. на дослідному полі Уманського НУС. Дослідження проводили відповідно до загальноприйнятих методик.

Досліджували сорти помідора української селекції Лагідний (контроль), Аніта, Айсан, Вулкан, Гейзер, Даруна, Класік, Любимий, Миролюбівський, Оберіг, Удавчик, Фізума, Хорів, Чудо. Схема розміщення рослин $70 \times 35 \mathrm{~cm}$. Облікова площа ділянки становила $6 \mathrm{~m}^{2}$.

У роботі застосовано основні методи дослідження: аналізу та порівняння, експериментальний, розрахунковий. Біометричні вимірювання рослин проводили перед висаджуванням розсади на постійне місце в поле, у період бутонізації, цвітіння, плодоутворення та на початку плодоношення за параметрами: висота, товщина стебла біля кореневої шийки, кількість листків до першої китиці, кількість продуктивних листків за фазами росту і розвитку рослин, асиміляційна поверхня, кількість квіток, що утворилися на першій китиці. Облік урожаю проводили три рази на тиждень. За кожного збирання плодів підраховували та зважували масу товарних і нетоварних плодів.

Результати досліджень. Проведення фенологічних та біометричних спостережень за ростом і розвитком рослин різних сортів помідора показало, що сортові особливості впливають на перебіг ростових процесів. У роки проведення досліджень за однакових строків сівби сходи з'являлися одночасно в усіх сортів. На швидкість проростання насіння більшою мірою впливають його посівні якості. 
Вивчення характеру прояву сортових особливостей помідора на настання основних фаз росту і розвитку підтвердило різний строк початку цвітіння, незважаючи на те, що вони належать до однієї групи стиглості. Серед сортів найраніше цвітіння рослин зафіксовано у сорту Миролюбівський - 27 травня, у сортів Оберіг, Хорів, Лагідний - 30 травня. Плоди в більшості сортів достигали в третій декаді липня, найраніше - у сорту Миролюбівський - 24 липня, що раніше контролю. У сортів Оберіг і Хорів - 29 липня, що пізніше контролю сорту Лагідний, у якого плоди достигали 28 липня. Залежно від сорту бутонізація першої китиці відбувалась на 43-46 добу після появи сходів (табл. 1).

Табл. 1. Скоростиглість сортів помідора (середнє за 2018-2020 рр.)

\begin{tabular}{|c|c|c|c|}
\hline \multirow[b]{2}{*}{ Сорт } & \multicolumn{2}{|c|}{ Кількість діб від сходів, до: } & \multirow{2}{*}{$\begin{array}{c}\text { Тривалість } \\
\text { вегетаційного } \\
\text { періоду, діб }\end{array}$} \\
\hline & $\begin{array}{c}\text { бутонізації } \\
\text { першої китиці }\end{array}$ & початку цвітіння & \\
\hline Лагідний (контроль) & 45 & 57 & 107 \\
\hline Аніта & 45 & 47 & 106 \\
\hline Айсан & 46 & 54 & 105 \\
\hline Вулкан & 45 & 56 & 105 \\
\hline Гейзер & 46 & 55 & 104 \\
\hline Даруна & 45 & 56 & 105 \\
\hline Класік & 46 & 57 & 105 \\
\hline Любимий & 45 & 55 & 103 \\
\hline Миролюбівський & 43 & 54 & 102 \\
\hline Оберіг & 46 & 57 & 106 \\
\hline Удавчик & 45 & 55 & 105 \\
\hline Фізума & 46 & 56 & 105 \\
\hline Хорів & 45 & 57 & 107 \\
\hline Чудо & 45 & 58 & 106 \\
\hline
\end{tabular}

Різниця у швидкості настання фази цвітіння між сортами коливалася в межах трьох діб. Найкоротшим вегетаційним періодом вирізнялися сорти Любимий, Миролюбівський, Удавчик, Фізума - 102-105 діб, Аніта, Оберіг і Чудо - 106, Хорів і Лагідний - 107 діб.

Аналіз одержаних результатів досліджень 3 визначення біометричних показників рослин помідора залежно від сорту дав можливість встановити, що за висотою головного стебла у фазу розсади більшість сортів мали близькі показники - 33,5-33,7 см, лише у Миролюбівського він був найменший 29,1 см (табл. 2). Виявлено незначне збільшення висоти головного стебла у фазу цвітіння першої китиці. На початку збирання плодів вона становила 71,371,8 см у сортів Хорів та Оберіг, Миролюбівський - 55,8 см порівняно з 68,4 см у контролі (сорт Лагідний). 
Табл. 2. Динаміка наростання біометричних показників вегетативної частини рослин помідора залежно від сорту (середнє за 2018-2020 рр.)

\begin{tabular}{|c|c|c|c|c|c|c|c|c|}
\hline \multirow[b]{2}{*}{ Показник } & \multirow{2}{*}{$\begin{array}{l}\text { Фаза росту i } \\
\text { розвитку } \\
\text { рослини }\end{array}$} & \multicolumn{7}{|c|}{ Copt } \\
\hline & & $\begin{array}{c}\text { Лагідний } \\
\text { (контроль) }\end{array}$ & Аніта & Вулкан & Оберіг & $\begin{array}{l}\text { Миролю- } \\
\text { бівський }\end{array}$ & Хорів & Чудо \\
\hline \multirow{3}{*}{$\begin{array}{l}\text { Висота } \\
\text { головного } \\
\text { стебла, см }\end{array}$} & $\begin{array}{l}\text { після } \\
\text { висаджування }\end{array}$ & 33,6 & 33,8 & 32,5 & 33,7 & 29,1 & 33,5 & 33,6 \\
\hline & $\begin{array}{l}\text { цвітіння } \\
\text { першої } \\
\text { китиці }\end{array}$ & 37,2 & 37,9 & 37,2 & 37,7 & 34,7 & 38,8 & 37,2 \\
\hline & $\begin{array}{l}\text { перед } \\
\text { збиранням } \\
\text { плодів }\end{array}$ & 68,4 & 69,2 & 70,2 & 71,8 & 55,8 & 71,3 & 68,4 \\
\hline \multirow{3}{*}{$\begin{array}{l}\text { Кількість } \\
\text { листків на } \\
\text { рослині, } \\
\text { шт. }\end{array}$} & $\begin{array}{l}\text { після } \\
\text { висаджування }\end{array}$ & 6 & 6 & 6 & 6 & 5 & 6 & 6 \\
\hline & $\begin{array}{l}\text { цвітіння } \\
\text { першої } \\
\text { китиці }\end{array}$ & 9 & 9 & 9 & 9 & 7 & 9 & 9 \\
\hline & $\begin{array}{l}\text { перед } \\
\text { збиранням } \\
\text { плодів }\end{array}$ & 37 & 38 & 39 & 45 & 28 & 41 & 37 \\
\hline
\end{tabular}

Перед висаджуванням у більшості сортів було 6 листків, у сорту Миролюбівський -5 шт. На два-три листки більше мали рослини помідора у фазу цвітіння першої китиці. На початку достигання плодів на рослинах налічували по 45 листків - сорт Оберіг, 41 - Хорів. Меншу кількість - 28 листків утворено у рослин сорту Миролюбівський, у контролі у сорту Лагідний було 37 шт/росл.

Площа листків на рослині змінювалася залежно від площі листка і їхньої кількості (рис.1). У фазу розсади площа листків становила 21,9 тис. м²/га у сорту Миролюбівський, у сортів Оберіг, Хорів - 24,3 тис. $\mathrm{m}^{2} /$ га, тобто мала близькі значення 3 контролем (21,3 тис. $\mathrm{m}^{2} /$ га). На період цвітіння цей показник збільшувався у сорту Оберіг до 52,8 тис. $\mathrm{m}^{2} /$ га, у сорту Хорів $-52,4$ тис. $\mathrm{m}^{2} /$ га, що порівняно із сортом Лагідний було істотно вищим - 45,2 тис. $\mathrm{m}^{2} /$ га. Найменшу площу листків мав сорт Любимий $-46,7$ тис. $\mathrm{m}^{2} /$ га. На початку достигання плодів площа листків досягала у сортів Хорів - 127,3 тис. м ${ }^{2} / г а$, Оберіг - 129,0 тис. $\mathrm{m}^{2} /$ га. У сорту Миролюбівський цей показник становив 125,5 тис. $\mathrm{m}^{2} /$ га, що менше порівняно $з$ 127,2 тис. $\mathrm{m}^{2} /$ га у контролі.

Отже, серед досліджуваних сортів помідора найменшу висоту головного стебла, кількість і площу листків на рослині мав сорт Миролюбівський. У сортів Оберіг і Хорів показники були вищі й наближалися до контролю сорту Лагідний.

Маса рослин у розсадному віці, $є$ важливим, показником ростових процесів після висаджування на постійне місце, і в значній мірі впливає на урожайність рослин. Проведені, дослідження з рослинами помідора свідчать, що показники як надземної частини, так і кореневої системи, залежали від біологічних особливостей досліджуваних сортів. 


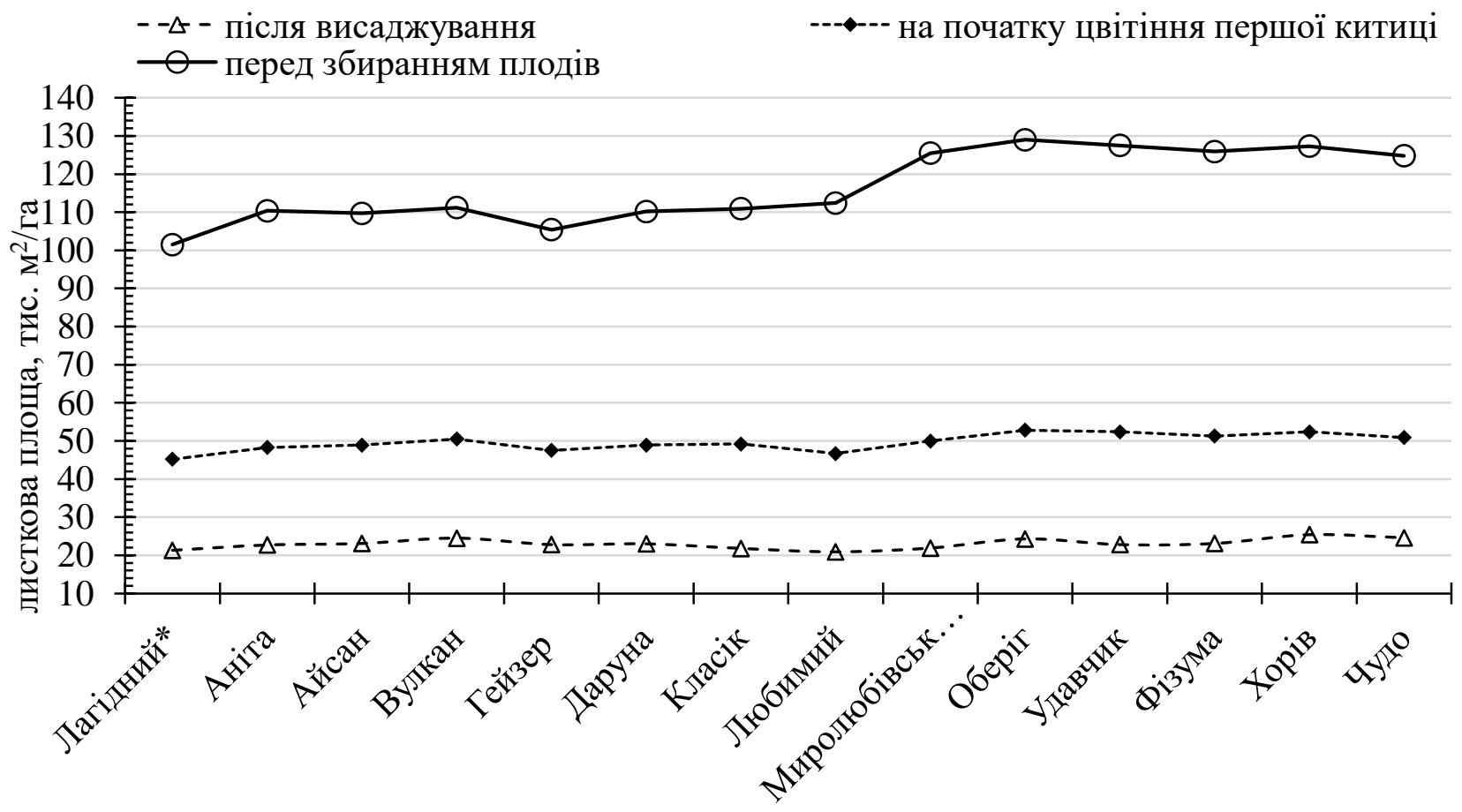

Рис. 1. Динаміка наростання загальної площі листків помідора залежно від сорту, тис. $\mathbf{m}^{2} / г$ (середне за 2018-2020 рр.)

Визначення даних показників проводили перед висаджуванням розсади на постійне місце (табл. 3).

Табл. 3. Якісні показники розсади помідора перед висаджуванням залежно від сорту (середнє за 2018-2020 рр.)

\begin{tabular}{|c|c|c|c|c|}
\hline \multirow[b]{2}{*}{ Сорт } & \multicolumn{2}{|c|}{ Сира маса, г } & \multirow{2}{*}{$\begin{array}{c}\text { Частка коренів } \\
\text { до надземної } \\
\text { частини, \% }\end{array}$} & \multirow{2}{*}{$\begin{array}{c}\text { Прижи- } \\
\text { вання } \\
\text { розсади, \% }\end{array}$} \\
\hline & $\begin{array}{c}\text { надземної } \\
\text { частини }\end{array}$ & $\begin{array}{l}\text { кореневої } \\
\text { системи }\end{array}$ & & \\
\hline $\begin{array}{l}\text { Лагідний } \\
\text { (контроль) }\end{array}$ & 58,7 & 9,9 & 16,9 & 97,5 \\
\hline Аніта & 63,2 & 11,3 & 17,9 & 100,0 \\
\hline Айсан & 56,9 & 9,2 & 16,2 & 97,5 \\
\hline Вулкан & 61,8 & 10,7 & 17,3 & 100,0 \\
\hline Гейзер & 58,7 & 9,9 & 16,9 & 97,5 \\
\hline Даруна & 63,2 & 11,3 & 17,9 & 100,0 \\
\hline Класік & 56,9 & 9,2 & 16,2 & 97,5 \\
\hline Любимий & 61,8 & 10,7 & 17,3 & 100,0 \\
\hline Миролюбівський & 58,7 & 9,9 & 16,9 & 97,5 \\
\hline Оберіг & 63,2 & 11,3 & 17,9 & 100,0 \\
\hline Удавчик & 56,9 & 9,2 & 16,2 & 97,5 \\
\hline Фізума & 61,8 & 10,7 & 17,3 & 100,0 \\
\hline Хорів & 63,2 & 11,3 & 17,9 & 100,0 \\
\hline Чудо & 61,8 & 10,7 & 17,3 & 100,0 \\
\hline
\end{tabular}

Маса надземної частини $\mathrm{HIP}_{05} 2018$ p. $=3,5$ 2; 2019 p. $=4,0$ 2; 2020 p. $=3,7$ г Маса кореневої системи $\mathrm{HIP}_{05} 2018$ p. $=0,29$ г; 2019 p. $=0,39$ г; $2020=0,31$ г 
Маса надземної частини рослин у варіантах досліду з вирощування різних сортів була у межах 56,9-63,2 г. Найбільшим даний показник був у сорту Оберіг - 63,2 г. Залежно від сорту маса коренів перед висаджуванням у розсади була різною. Найбільшу сиру масу коренів на період висаджування відзначено у сортів Хорів та Оберіг - 10,7-11,3 г. Частка маси кореневої системи до маси наземної частини рослини у досліді знаходилась у межах 16,2-17,9 \%.

Таким чином, вирощування розсади різних сортів впливає на біометричні показники рослин та загальну масу розсади, величину іiі органів, а також впливає на розмір частки кореневої системи до надземної частини рослини.

Найвищий відсоток приживання розсади у сортів Хорів та Оберіг $-100 \%$, що більше порівняно 3 контролем сортом Лагідний на 2,5\%. Тому, розсада 3 більшим відсотком співвідношення кореневої системи до надземної маси забезпечує кращий відсоток приживання рослин.

Порівняння кількості генеративних органів рослин, які досліджувалися, показало, що сорт Хорів був найпродуктивнішим (рис. 2). Упродовж періоду вегетації найбільша кількість китиць утворювалася на рослинах сорта Хорів 23,1 шт/росл., найменша на рослинах гібрида Лагідний - 20,8 шт/росл.

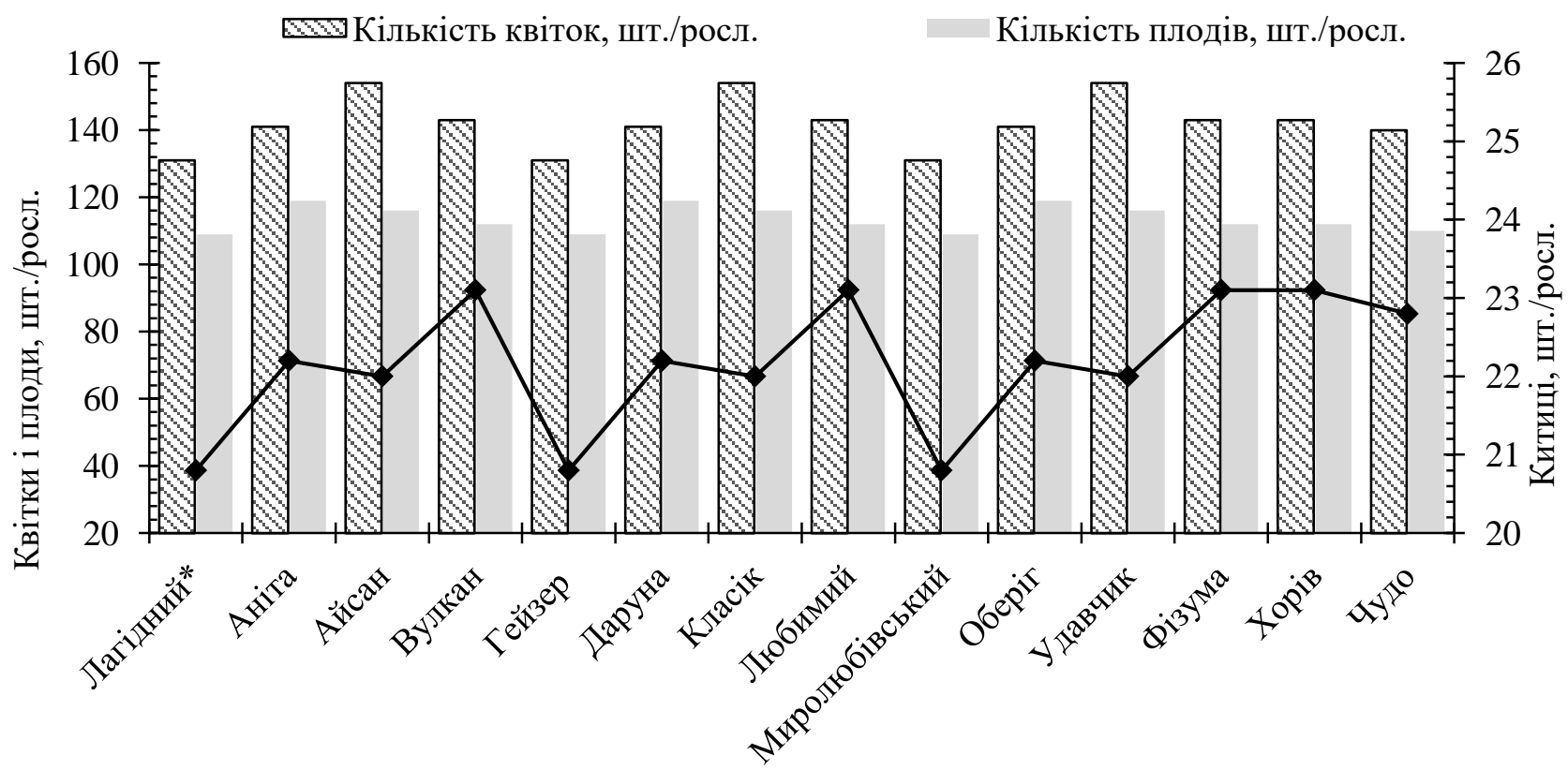

\section{Рис. 2. Господарсько-біологічні показники сортів помідора, (середнс за 2018 - 2020 рр.)}

Кількість квіток та плодів на рослинах одного сорту була не пропорційною. Це можна пояснити ступенем зав'язування плодів. Так, за найбільшої кількості квіток у сорту Миролюбівський плодів утворювалося значно менше, що зумовлено найнижчим показником зав'язування - $74 \%$. Найвищу кількість плодів відмічали у сорту Оберіг, ступінь зав'язування якого становив $85 \%$.

За масою товарного плоду також виділявся сорт Хорів, найменшу мали сорти Аніта, Оберіг і Удавчик - 78-80 г. У сортів Айсан, Миролюбівський маса 
плоду була в межах 83 г, але за рахунок меншої кількості плодів на китиці й рослині врожайність була нижчою. Вищою масою плоду відзначилися останні сорти помідора, у яких маса була у межах 85-94 г (рис. 3).

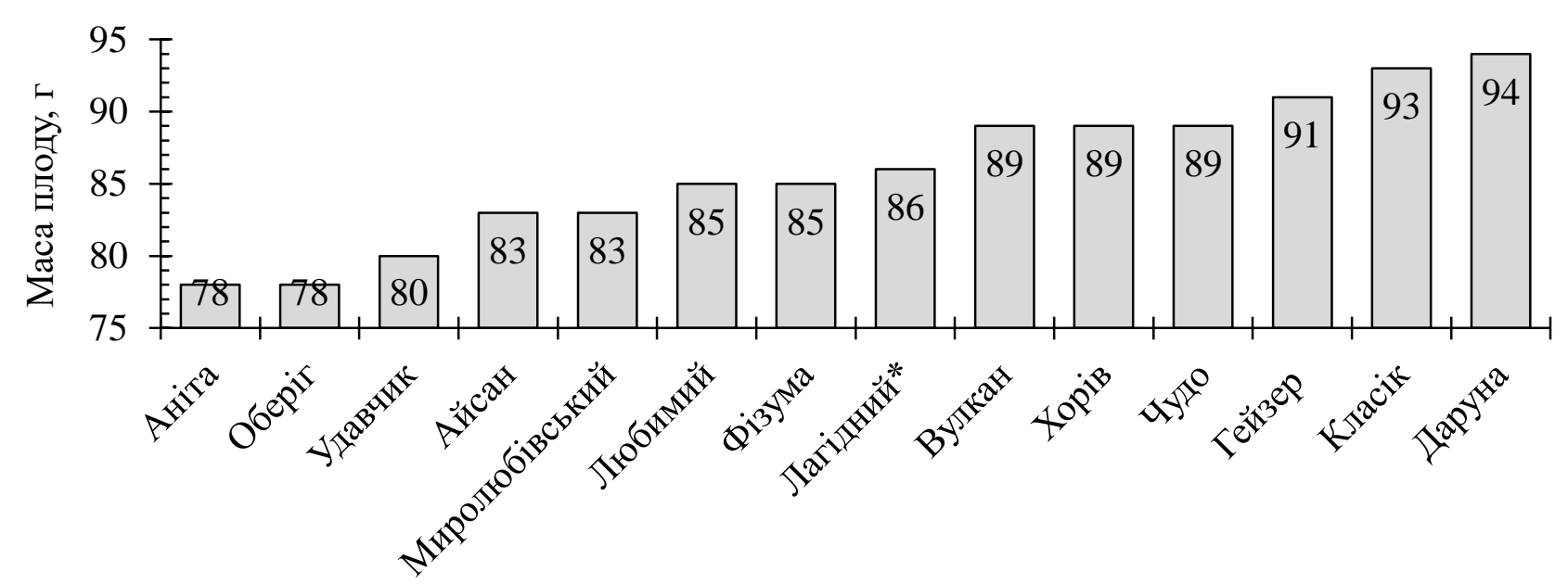

\section{Рис. 3. Маса плоду помідора залежно від сорту, г (середне за 2018-2020 рр.)}

Вихід товарної продукції в усіх сортів є високим 98,3-99,9 \%. Плоди транспортабельні, менше пошкоджуються.

Урожайність помідора зумовлена багатьма чинниками, серед яких одним 3 найважливіших є сорт. У свою чергу, кожен сорт характеризується певними морфологічними ознаками й біологічними особливостями, властивими лише йому (рис. 4).

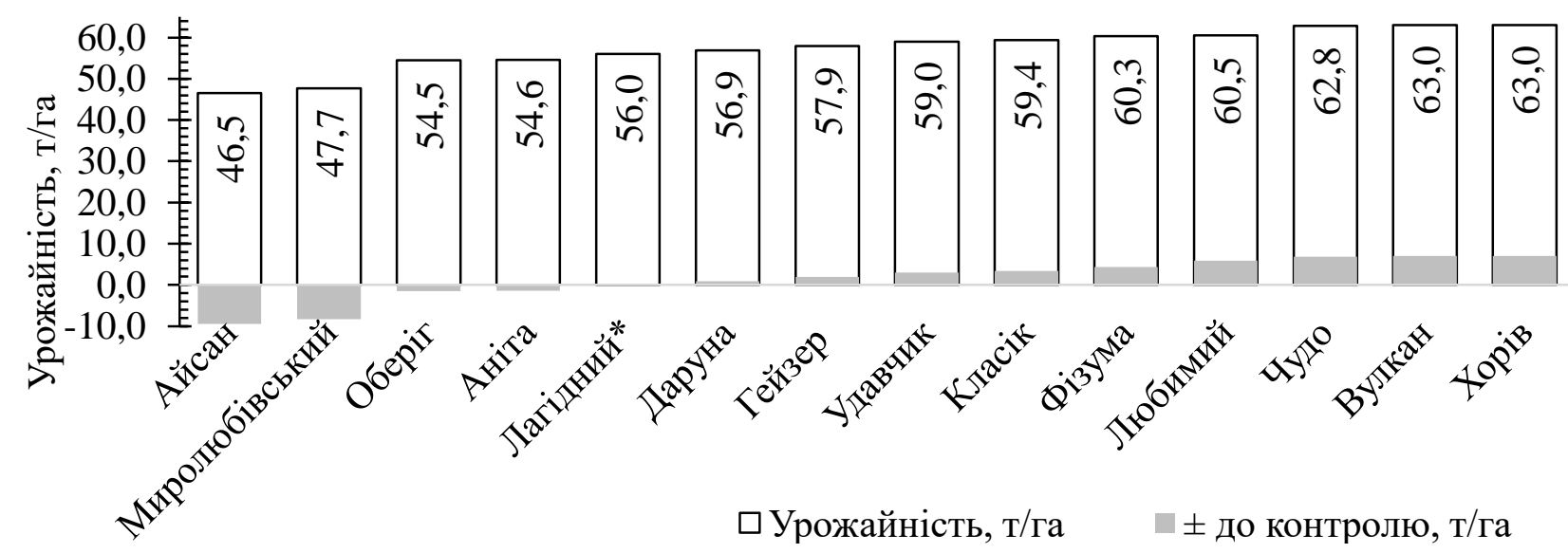

Урожайність HIP 052018 p. $=4,7 \mathrm{~m}, 2019$ p. $=1,3 \mathrm{~m}, 2020=2,1 \mathrm{~m}$

\section{Рис. 4. Урожайність товарних плодів помідора залежно від сорту, г (середнс за 2018-2020 рр.).}

Серед сортів помідора найвищу врожайність забезпечили сорти Вулкан і Хорів - 63,0 т/га і Чудо - 62,8 т/га, які істотно перевищували контроль (сорт Лагідний) - 56,0 т/га. Сорт Даруна наближався за цим показником до контролю сорту Лагідний і мав врожайність 56,9 т/га. У сортів Аніта і Оберіг врожайність була нижчою від контролю на 1,4-1,5 т/га, а у сортів Миролюбівський і Айсан 
на 8,3-9,5 т/га.

У ході аналізу результатів трирічних досліджень встановлено, що серед сортів помідора за всіма господарськими показниками перевагу мали сорти Чудо, Вулкан і Хорів.

Важливим показником якості плодів помідора незалежно від форми плоду $є$ біохімічний склад тобто вміст сухої розчинної речовини, цукрів, кислот, вітаміну С (табл. 4).

Табл. 4. Хімічний склад плодів помідора залежно від сорту

\begin{tabular}{|l|c|c|c|c|}
\hline \multirow{2}{*}{ Сорт } & \multicolumn{4}{|c|}{ Вміст } \\
\cline { 1 - 5 } & $\begin{array}{c}\text { сухої розчинної } \\
\text { речовини, \% }\end{array}$ & $\begin{array}{c}\text { суми } \\
\text { цукрів, \% }\end{array}$ & $\begin{array}{c}\text { титрованих } \\
\text { кислот, \% }\end{array}$ & $\begin{array}{c}\text { вітаміну С, } \\
\text { мг } 100 \text { г }\end{array}$ \\
\hline $\begin{array}{l}\text { Лагідний } \\
\text { (контроль) }\end{array}$ & 4,9 & 3,0 & 0,40 & 24,0 \\
\hline Аніта & 5,1 & 3,4 & 0,40 & 24,0 \\
\hline Айсан & 5,0 & 3,8 & 0,68 & 23,2 \\
\hline Вулкан & 5,1 & 3,2 & 0,40 & 24,0 \\
\hline Гейзер & 5,3 & 3,8 & 0,68 & 23,2 \\
\hline Даруна & 5,4 & 3,0 & 0,40 & 24,0 \\
\hline Класік & 5,1 & 3,8 & 0,68 & 23,2 \\
\hline Любимий & 5,5 & 3,0 & 0,40 & 24,0 \\
\hline Миролюбівський & 5,1 & 3,8 & 0,68 & 23,2 \\
\hline Оберіг & 6,2 & 3,9 & 0,41 & 25,4 \\
\hline Удавчик & 5,1 & 3,8 & 0,68 & 23,2 \\
\hline Фізума & 5,3 & 4,0 & 0,40 & 24,0 \\
\hline Хорів & 5,0 & 3,4 & 0,61 & 25,3 \\
\hline Чудо & 5,2 & 4,3 & 0,60 & 23,1 \\
\hline
\end{tabular}

Одержані результати свідчать, що найвищі хімічні показники мав сорт Оберіг. Його плоди накопичували 6,2 \% сухої розчинної речовини проти контролю Лагідний 5,1%. Сорти Хорів і Миролюбівський за цим показником наближалися до стандарту. За вмістом цукрів переважали сорти Оберіг i Миролюбівський - 3,9 і 3,8 \% відповідно порівняно з 3,0 \% у Лагідного, сорт Хорів мав суму цукрів на рівні 3,4\%.

За кількістю вітаміну С виділялися сорти Оберіг і Чудо, у яких виявлено найвищий цукрово-кислотний коефіцієнт - 9,4 порівняно 3 контролем $(7,5)$. У сортів Хорів і Миролюбівський він був на рівні 5,6 і 5,8 відповідно. Отже, серед сортів помідора кращим біохімічним складом характеризувалися сорти Вулкан, Оберіг, Чудо. 
Висновки. На підставі одержаних експериментальних даних пропонуємо у Правобережному Лісостепу України вирощувати сорти помідора Чудо, Вулкан i Хорів, що дозволяє отримати 62,8-63,0 т/га високоякісних плодів за рахунок кращого приживлення розсади, збільшення біометричних показників.

Плоди сорт Оберіг накопичували 6,2 \% сухої розчинної речовини проти контролю Лагідний 5,1%. Сорти Хорів і Миролюбівський за цим показником наближалися до стандарту. За вмістом цукрів переважали сорти Оберіг і Миролюбівський - 3,9 і 3,8 \% відповідно порівняно з 3,0 \% у Лагідного, сорт Хорів мав суму цукрів на рівні $3,4 \%$.

За кількістю вітаміну С виділялися сорти Оберіг і Чудо, у яких виявлено найвищий цукрово-кислотний коефіцієнт - 9,4 порівняно з контролем $(7,5)$. У сортів Хорів і Миролюбівський він був на рівні 5,6 і 5,8 відповідно. Отже, серед сортів помідора кращим біохімічним складом характеризувалися сорти Вулкан, Оберіг, Чудо.

\section{Література}

1. Кравченко В. А. Помідор. Селекція, насінництво, технології. К.: Аграрна наука, 2007. 405 с.

2. FAOSTAT, 2014, Food balance sheets. http://faostat.fao.org (dostęp 26.09.2020).

3. Мязина Л. А. Биологические особенности и комплексная оценка лёжкоспособных форм томата: Автореф. дис. канд. с.-х. наук: 06.01.06, 06.01.05. M., 1997. 24 c.

4. Практический справочник овощевода. Томат. Справочное издание. Киев: Юнивест Медиа, 2010. 256 с.

5. Роганіна В. С. Планування розвитку овочівництва на основі інновацій. Вісник Харківського нащіонального аграрного університету ім. В. В. Докучаєва. 2013. № 8. С. 132-137.

6. Бондаренко Г. Л., Яковенко К. І. Методика дослідної справи в овочівництві і баштанництві. Харків: Основа, 2001. 369 с.

7. Рудас Л. А. Генетичне обгрунтування методів створення сортів i гетерозисних гібридів помідора для тривалого зберігання плодів. Дис. канд. с.г. наук: 05.01.06. Сміла, 2006. $176 \mathrm{c.}$

8. Степанова I. М. Залежність врожаю та якості плодів посівного томата від сорту, добрив, густоти стояння рослин і зрошення в умовах Півдня України: Дис. канд. с.-г. наук: 01.04.18. Інститут землеробства Української академії аграрних наук. Херсон, 2005. 177 арк.

9. Томати свіжі. Технічні умови ДСТУ 3246-95. [Чинний від 01.01.1997]. К.: Держспоживстандарт України, 2007. 13 с.

10. Філімонов Ю. Л. Сучасний стан овочівництва відкритого грунту. Вісник ХНАУ. 2002. № 7. С. $230-234$.

11. Deeker W. Engineering tastier tomatoes. Rural Research. 1994. 162. P. 24-26.

12. Leal N. R., Tabim M. N. Tested de conservacao natural poscolheita alem 
dos 300 dias dos frutos de alguns cultivars de tomatiero e hibridos destes com “Alcobaca". Rev. Ceres. 1974. № 21. P. 310-328.

13. Smith C. J. S., Watson C. F., Ray J. et al. Antisense RNA inhibition of polygalacturonase gene expression in in transgenic tomatoes. Nature. 1988. № 33. P. 724-726.

14. Abushita A. A., Hebshi E. A., Daood H. G. et al. Determination of antioxidant vitamins in tomatoes. Food Chemistry. 1997. № 60. P. 207-212.

15. Antosiewicz J., Damiani E., Jassem W. et al. Influence of structure on the antioxidant activity of indolinic nitroxide radicals. Free Radical Biology and Medicine. 1997. № 22. P. 249-255.

16. Bogacz K. Pomidor - idealne źródło witamin, substancji odżywczych i prozdrowotnych. Przemyst Fermentacyjny i Owocowo-Warzywny. 2011. № 7. P. 3435 .

17. Charanjeet K., George B., Deepa N. et al. Antioxidant status of fresh and processed tomato - a review. Journal of Food Sciences and Technology. 2004. № 41. P. 479-485.

18. Compos F. M., Chaves J. B, Raquel M. C. et al. Adequate handling conditions to presevve vitamin $\mathrm{C}$ and Carotenoids in tomatoes. Journal of Food Quality. 2010. № 33. P. 230-245.

19. Czapski J., Walkowiak-Tomczak D. Nowe surowce i technologie w produkcji soków jako odpowiedź na oczekiwania konsumenta. Przemyst Fermentacyjny i Owocowo-Warzywny. 2001. № 3. P. 15-17.

20. Czapski J. Trendy $\mathrm{w}$ technologii aktywnych opakowań żywności ze szczególnym uwzględnieniem produktów owocowo-warzywnych. Przemyst Fermentacyjny i Owocowo-Warzywny. 2007. № 10. P. 36-38.

21. Giovannucci E. Tomatoes, tomato - base products. Lycopene and cancer: reviev of epidemiologic literature. Journal of the National Cancer Institute. 1999. № 91. P. 317-331.

22. Krugła E., Zdziennicka D., Kostrzewa E. Napoje i soki owocowowarzywne jako nośniki składników funkcjonalnych. Przemyst Spożywczy. 2001. № 3. P. 20-21.

23. Marx M., Stuparic M., Schieber A. et al. Effect of thermal processing on trans-cis-isomerization of $\beta$-carotene in carrot juices and carotene containing preparations. Food Chemistry. 2003. № 83. P. 609-617.

\section{References}

1. Kravchenko, V. A. (2007). Tomato. Breeding, seed production, technologies. K.: Ahrarna nauka, 405 p.

2. FAOSTAT (2014). Food balance sheets. http://faostat.fao.org (dostęp 26.09.2020).

3. Myazyna, L. A. (1997). Biological features and a comprehensive assessment of mature forms of tomato: Avtoref. dys. kand. s.-kh. nauk: 06.01.06, 06.01.05. M., $24 \mathrm{p}$.

4. Practical guide to vegetable growing. Tomato. Reference edition (2010). 
Kyev: Yunyvest Medya, $256 \mathrm{p}$.

5. Rohanina V. Ye. (2013). Vegetable development planning based on innovations. Bulletin of Kharkiv National Agrarian University named after V. V. Dokuchaev, no. 8, pp. 132-137.

6. Bondarenko, H. L., Yakovenko, K. I. (2001). Methods of research in vegetable growing and melon growing. Kharkiv: Osnova, $369 \mathrm{p}$.

7. Rudas, L. A. (2006). Genetic substantiation of methods of creation of grades and heterosis hybrids of a tomato for long storage of fruits. Dys. kand. s.-h. nauk: 05.01.06. Smila, $176 \mathrm{p}$.

8. Stepanova, I. M. (2005). Dependence of yield and quality of tomato fruits on variety, fertilizers, plant density and irrigation in the South of Ukraine. Dys. kand. s.h. nauk: 01.04.18. Kherson, 177 p.

9. Fresh tomatoes. Technical conditions of DSTU 3246-95. [Effective from 01.01.1997]. K .: Derzhspozhyvstandart Ukrainy, 2007. 13 p.

10. Filimonov, Yu. L. (2002). The current state of open field vegetable growing. Bulletin of KhNAU, no. 7, pp. $230-234$.

11. Deeker W. (1994). Engineering tastier tomatoes. Rural Research, no. 162, pp. 24-26.

12. Leal, N. R., Tabim, M. N. (1974). Tested de conservacao natural poscolheita alem dos 300 dias dos frutos de alguns cultivars de tomatiero e hibridos destes com "Alcobaca". Rev. Ceres., no. 21, pp. 310-328.

13. Smith, C. J. S., Watson, C. F., Ray, J. et al. (1988). Antisense RNA inhibition of polygalacturonase gene expression in in transgenic tomatoes. Nature, no. 33, pp. 724-726.

14. Abushita, A. A., Hebshi, E. A., Daood, H. G. et al. (1997). Determination of antioxidant vitamins in tomatoes. Food Chemistry, no. 60, pp. 207-2012.

15. Antosiewicz, J., Damiani, E., Jassem, W. et al. (1997). Influence of structure on the antioxidant activity of indolinic nitroxide radicals. Free Radical Biology and Medicine, no. 22, pp. 249-255.

16. Bogacz, K. (2011). Pomidor - idealne źródło witamin, substancji odżywczych i prozdrowotnych. Przemyst Fermentacyjny $i$ Owocowo-Warzywny, no. 7, pp. 34-35.

17. Charanjeet, K., George, B., Deepa, N. et al. (2004). Antioxidant status of fresh and processed tomato - a review. Journal of Food Sciences and Technology 2004, no. 41, pp. 479-485.

18. Compos, F. M., Chaves, J. B., Raquel, M. C. et al. (2010). Adequate handling conditions to presevve vitamin $\mathrm{C}$ and Carotenoids in tomatoes. Journal of Food Quality, no. 33, pp. 230-245.

19. Czapski, J., Walkowiak-Tomczak, D. (2001). Nowe surowce i technologie w produkcji soków jako odpowiedź na oczekiwania konsumenta. Przemyst Fermentacyjny i Owocowo-Warzywny, no. 3, pp. 15-17.

20. Czapski, J. (2007). Trendy w technologii aktywnych opakowań żywności ze szczególnym uwzględnieniem produktów owocowo-warzywnych. Przemyst Fermentacyjny i Owocowo-Warzywny, no. 10, pp. 36-38. 
21. Giovannucci, E. (1999). Tomatoes, tomato - base products. Lycopene and cancer: reviev of epidemiologic literature. Journal of the National Cancer Institute, no. 91, pp. 317-331.

22. Krugła, E., Zdziennicka, D., Kostrzewa. E, (2001). Napoje i soki owocowo-warzywne jako nośniki składników funkcjonalnych. Przemyst Spożywczy, no. 3, pp. 20-21.

23. Marx, M., Stuparic, M., Schieber, A. et al. (2003). Effect of thermal processing on trans-cis-isomerization of b-carotene in carrot juices and carotene containing preparations. Food Chemistry, no. 83, pp. 609-617.

\section{Аннотация}

\section{Воробйова Н. В.}

Адаптивность и урожсайность сортов помидора в Лесостепи Украины

Расширение сортимента овощных растений позволяет увеличить разнообразие и производство отечественной овощной продукиии, в частности, помидора. В статье рассмотрены и доказаны результаты исследований, что сорт существенно влияет на формирование урожайности помидора и может минимизировать негативное влияние факторов окружающей среды.

Экспериментальные исследования проводили в 2018-2020 г2. На опытном поле Уманского НУС и проводили в соответствии с общепринятыли методиками. В работе применены основные методы исследования: анализа и сравнения, экспериментальный, расчетный. Исследовали сорта помидора украинской селекиии Лагидный (контроль), Анита, Айсан, Вулкан, Гейзер, Даруна, Классик, Любимылй, Миролюбовский, Оберег, Удавчик, Физума, Хорив, Чудо.

Изучение характера влияния сортовых особенностей помидора на наступление основных фаз роста и развития подтвердило разный срок начала иветения и у сорта Миролюбовский период наступал 27 мая, у сортов Оберег, Хорив, Лагидныий - 30 мая. Плодь у большинства сортов достигали в третьей декаде июля, у сорта Миролюбовский - 24 июля, у сортов Оберег и Хорив 29 июля, позже контроля. В зависимости от сорта бутонизация первой кисти происходила на 43-46 сутки после появления всходов. Самым коротким вегетачионным периодом отличались сорта Любимый, Миролюбовский, Удавчик, Физума - 102-105 суток, Анита, Оберег и Чудо - 106, Хорив и Лагидный - 107 суток.

Установлено, что по высоте главного стебля в фазу рассады большинство сортов имели близкие показатели - 33,5-33,7 cм, только у сорта Миролюбовский он был наименьший - 29,1 см. Выявлено незначительное увеличение высоты главного стебля в фазу иветения первой кисти и до начала сбора плодов она составляла 71,3-71,8 см у сортов Хорив и Оберег, Миролюбовский - 55,8 см. Перед высадкой у большинства сортов наблюдалось по 6 листьев, у сорта Миролюбовский - 5. В начале созревания плодов на растениях насчитывали по 45 листьев у сорта Оберег, 41 - Хорив, 28 Миролюбовский, что существенно выше контроля сорта Лагидный $37 \mathrm{~mm} / \mathrm{pacm}$.

Площадь листьев на растении изменялась в зависимости от площади листовой пластинки и их количества. В фазу рассады площадь листьев 
составляла 21,9 тыс. м²/га у сорта Миролюбовский, у сорта Оберег 24,3 mыс. $\mathrm{m}^{2} / 2 a$, то есть имела близкие значения с контролем (21,3 mblс. $\left.\mathrm{M}^{2} / 2 a\right)$. На период иветения этот показатель увеличивался у сорта Оберег до

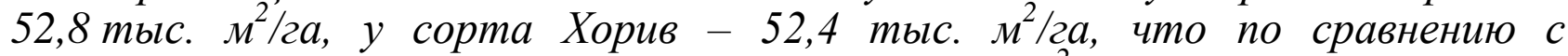
контролем было сушественно выше - 45,2 mыс. м $^{2} / 2 a$. В начале созревания плодов площуадь листьев достигала у сортов Хорив - 127,3 mblc. $\mathrm{m}^{2} / 2 а$, Оберег-

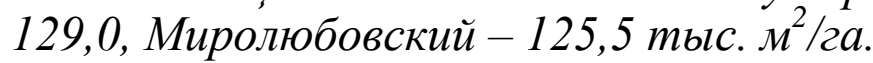

Сравнение количества генеративных органов растений помидора показало, что в течение периода вегетации большее количество кистей образовывалось на растениях сорта Хорив - 23,1 иm/pacm., что превышало контроль - 20,8 $\mathrm{um} / \mathrm{pacm}$.

Наивысшую урожайность имели сорта Вулкан и Хорив - 63,0 m/2a, а также Чудо - 62,8 m/2a, что существенно превышало контроль - 56,0 m/2a. Сорт Даруна приближался по этому показателю и имел урожайность 56,9 m/2а. У сортов Анита и Оберег урожайность была ниже контроля на 1,41,5 m/2а, у сортов Миролюбовский и Айсан - на 8,3-9,5 m/2а.

Высокие химические показатели имел сорт Оберег, плоды которого накапливали 6,2% сухого растворимого вещества против контроля Лагидный $5,1 \%$. Сорта Хорив и Миролюбовский по этому показателю приближались $к$ контролю. По содержанию сахаров преобладали сорта Хорив, Оберег и Миролюбовский - 3,4, 3,9 и 3,8\% соответственно, что существенно выше контроля. По количеству витамина С выделялись сорта Оберег и Чудо, у которых обнаружен высокий сахарно-кислотный коэффициент - 9,4 по сравнению с контролем (7,5). У сортов Хорив и Миролюбовский он был на уровне 5,6 и 5,8 соответственно.

Ключевые слова: помидор, сорт, лист, листовая поверхность, урожайность, качество плодов.

\section{Annotation}

\section{Vorobjova $N . V$.}

\section{Adaptability and productivity of tomato varieties in the forest-steppe of Ukraine}

The expansion of the assortment of vegetable plants allows to increase the variety and production of domestic vegetable products, in particular, tomatoes. The article examines and proves the research results that the variety significantly affects the formation of tomato productivity and can minimize the negative impact of environmental factors.

Experimental studies were carried out in 2018-2020. On the experimental field of the Uman NUS and was carried out in accordance with generally accepted methods. The main research methods are used in the work: analysis and comparison, experimental, calculated. We studied tomato varieties of Ukrainian selection Lagidny (control), Anita, Aisan, Vulkan, Geyser, Daruna, Classic, Lyubimy, Mirolyubovsky, Obereg, Udavchik, Fizuma, Khoriv, Chudo.

The study of the nature of the influence of the varietal characteristics of the tomato on the onset of the main phases of growth and development confirmed the different timing of the beginning of flowering and in the variety Mirolyubovsky period began on May 27, in the varieties Obereg, Khoriv, Lagidny - on May 30. The fruits of most varieties reached in the third decade of July, in the Mirolyubovsky variety - on July 24, in the Obereg and Khoriv varieties - on July 29, later than control. 
Depending on the variety, budding of the first cluster occurred 43-46 days after germination. The shortest growing season was observed in the varieties Lyubimy, Mirolyubovsky, Udavchik, Fizuma - 102-105 days, Anita, Obereg and Chudo-106, Horev and Lagidny - 107 days.

It was found that in terms of the height of the main stem in the seedling phase, most varieties had similar indicators - 33.5-33.7 cm, only in the Mirolyubovsky variety it was the smallest $-29.1 \mathrm{~cm}$. An insignificant increase in the height of the main stem was revealed in the flowering phase of the first cluster and before the start of fruit collection, it was 71.3-71.8 cm in varieties Khoriv and Obereg, Mirolyubovsky - $55.8 \mathrm{~cm}$. Before planting, most varieties had 6 leaves, and in Mirolyubovsky variety - 5. At the beginning of ripening, fruits on plants were counted by 45 leaves in the Oberig variety, 41 - Khoriv, 28 - Mirolyubovsky, which is significantly higher than the control of the Lagidny variety - 37 pcs/plant.

The area of leaves on the plant varied depending on the area of the leaf blade and their number. In the seedling phase, the leaf area was 21.9 thousand. $\mathrm{m}^{2} / \mathrm{ha}$ for the Mirolyubovsky variety, for the Obereg variety - 24.3 thousand $\mathrm{m}^{2} / \mathrm{ha}$, ie had close values with control (21.3 thousand $\mathrm{m}^{2} / \mathrm{ha}$ ). At the time of flowering, this figure increased for the variety Obereg to 52.8 thousand $\mathrm{m}^{2} / \mathrm{ha}$, in the variety Horiv 52.4 thousand $\mathrm{m}^{2} / \mathrm{ha}$, which was significantly higher than the control - 45.2 thousand $\mathrm{m}^{2} / \mathrm{ha}$. At the beginning of fruit ripening, the leaf area reached 127.3 thousand $\mathrm{m}^{2} / \mathrm{ha}$, Obereg - 129.0, Mirolyubovsky - 125.5 thousand $\mathrm{m}^{2} / \mathrm{ha}$.

Comparison of the number of generative organs of plants showed that during the growing season a larger number of brushes was formed on plants of the Horeb variety - 23.1 pieces/plant, which exceeded the control-20.8 pieces / plant.

The highest yields were found in the varieties Vulkan and Khoriv - $63.0 \mathrm{t} / \mathrm{ha}$, as well as Miracle - 62.8 t/ha, which significantly exceeded the control - $56.0 \mathrm{t} / \mathrm{ha}$. The Daruna variety approached this indicator and had a yield of $56.9 \mathrm{t} / \mathrm{ha}$. In varieties Anita and Obereg, the yield was lower than the control by 1.4-1.5 t/ha, in varieties Mirolyubovskiy and Aisan - by 8.3-9.5 t/ha.

The variety Oberig had high chemical indicators, the fruits of which accumulated $6.2 \%$ of dry soluble substance versus $5.1 \%$ control Lagidny. The varieties Khoriv and Mirolyubovsky were close to the control in terms of this indicator. In terms of sugar content, varieties Khoriv, Obereg and Mirolyubovsky prevailed - 3.4, 3.9 and $3.8 \%$, respectively, which is significantly higher than the control. In terms of the amount of vitamin $C$, the varieties Oberig and Chudo were distinguished, in which a high sugar-acid coefficient was found-9.4 compared to the control (7.5). In varieties Khoriv and Mirolyubovsky, it was at the level of 5.6 and 5.8 , respectively.

Key words: tomato, variety, leaf, leaf surface, yield, fruit quality. 